\title{
Biogeosorbents for solving environmental problems
}

\author{
D. A. Shushkov'1, O. B. Kotova1, T. N. Shchemelinina' ${ }^{2}$, M. Harja ${ }^{3}$, E. M. Anchugova2 \\ ${ }^{1}$ Institute of Geology FRC Komi SC UB RAS, Syktyvkar; dashushkov@geo.komisc.ru \\ 2Institute of Biology FRC Komi SC UB RAS, Syktyvkar

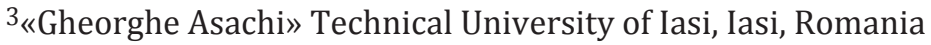

\begin{abstract}
The pollution of land and water objects by hydrocarbons during exploration, production, transportation, storage and processing remains an important environmental problem. The problem of restoring land and water objects, polluted after accidental spills, is especially relevant for the Northern and Arctic territories, which are char-
\end{abstract}

acterized by low regeneration. The most common waste is phenol and its derivatives, which belong to the group of dangerous pollutants. The input of phenols into waters has a negative effect on the hydrochemical mode of the water object: the oxygen content decreases, the color and oxidizability increase. 
The work is aimed at the creation of biogeosorbents and testing of their sorption and destructive properties in relation to oil products and phenols.

Mineral carriers were natural sorbents based on mineral raw from the European North-East of Russia: analcime-containing rocks of the Veslyana occurrence of the Koinskaya zeolite area [1], clinoptilolite-containing clays and glauconite-containing rocks of the Chim-Loptyuga oil shale field [2].

The strains, included in the Biotrin biological product [3], were used as oil destruction organisms: bacteria Pseudomonas yamanorum VKM B-3033D [4]; yeast Rhodotorula glutinis, VKM Y-2998D [5]; microalgae Chlorella vulgaris Beijer. f. globosa V. Andr. As organisms of phenol destructors, microalgae Chlorella vulgaris Beijer f. globosa V. Andr. were used.

The sorption and destructive properties of the initial sorbents and simulated biogeosorbents in relation to oil products are evaluated. We determined that the samples of the initial sorbents exhibited a high adsorption activity with respect to oil products, reducing the oil product content by 2.55 times (standard or significantly lower than MAC standard).

During the immobilization of microorganism cells on the surface of mineral carriers we revealed decreasing sorption properties, but at the same time, the microorganisms provided biodegradation of hydrocarbons, which during 4 days was 60 to $77 \%[6,7]$. The ratio of normal alkanes changes, lighter alkanes degrade faster. Samples of calcitecontaining rocks and clinoptilolite-containing clay can retain low molecular alkanes, which are usually subject to weathering.

We evaluated sorption and destructive properties of the initial sorbents, a suspension of microalgae, and simulated biogeosorbents in relation to phenols. The advantage of the synergetic complex of the biogeosorbent from its individual components was revealed: decreasing period of water purification from phenols. Biodegradation of $83 \%$ of phenols in the model water occurs in 3 days.

We showed that the mineral carrier ensured safety and increases the growth of microalgae cells under stress conditions. Microalgae Chlorella vulgaris immobilized on analcime-containing rocks showed tolerance to increased salinity (34\%o) and organic pollutants (phenolic water with a concentration of $10 \mu \mathrm{g} / \mathrm{dm}^{3}$ ) [8].

The authors express gratitude to Geonauka Center for Collective Use and the eco-analytical laboratory of the Institute of Biology of Komi SC UB
RAS for their help in the analytical work. This work was financially supported by State Assignment No. AAAA-A17-117121270025-1 "Development of biocatalytic systems based on enzymes, microorganisms and plant cells, their immobilized forms and associations for processing plant materials, obtaining biologically active substances, biofuels, remediation of contaminated soils and cleaning wastewater" and No. AAAA-A17-117121270037-4 "Scientific foundations of effective subsoil use, development and development of the mineral resource base, development and implementation of innovative technologies, geological and economic zoning of the Timan-Northern Ural region".

\section{References}

1. Kotova O. B., Harja M., Cretescu I., Noli F., Pelovski Y., Shushkov D. A. Zeolites in technologies of pollution prevention and remediation of aquatic systems // Vestnik of the Institute of Geology of Komi SC UB RAS, 2017, No. 5, pp. $49-53$.

2. Saldin V. A., Burtsev I. N., Mashin D. O., Shebolkin D. N., Inkina N. S. Marking horizons in the Upper Jurassic deposits of the Yarengsky shale-bearing region (northeast of the Russian Plate). Vestnik of Institute of geology Komi SC UB RAS, 2013, No. 11, pp. 26-29. (in Russian)

3 . Conclusion on the toxicological and hygienic assessment of «Biotrin» consortium of strains of oil-oxidizing microorganisms. SRC branch of "SSC Institute of Immunology". Serpukhov, 28.09.2017. (in Russian)

4. RF Patent No. 2615458. The bacterial strain Pseudomonas yamanorum VKM B-3033D for activating biodegradation of oil and oil products in water and in oil soils in railway sections. Bioecobalans LLC; S. M. Meshkelo, T. N. Schemelinina, E. M. Anchugova. Announced 02.07.2016, published 20.06.2018, No.17. (in Russian)

6. Shchemelinina T. N., Kotova O. B., Anchugova E. M., Shushkov D. A., Ignatiev G. V. Zeolite and clay raw: experimental modeling of biogeosorbents. Vestnik of the Institute of Geology, Komi SC UB RAS, 2018, No. 9, pp. 50-57. (in Russian)

7. RF patent No. 2715036. Biogeosorbent for cleaning oil-contaminated water objects. T. N. Shchemelinina, E. M. Anchugova, M. Yu. Markarova, O. B. Kotova, D. A. Shushkov, G. V. Ignatiev. Announced 27.12.2018. Published 21.02.2020. No. 6. (in Russian)

8. Shchemelinina T. N., Anchugova E. M., Kotova O. B., Sun S., Shushkov D. A., Gogonin A. V., Likhanova N. V., Zueva O. M., Korchagina Yu. S. Why mineral carriers are necessary for microalgae. Vestnik of Geosciences, 2020, 2, pp. $24-28$. 